\title{
BMJ Global Health Plain packaging of tobacco products: the logical next step for tobacco control policy in India
}

To cite: Yadav A, Nazar GP, Rawal T, et al. Plain packaging of tobacco products: the logical next step for tobacco control policy in India. BMJ Glob Health 2018;3:e000873. doi:10.1136/ bmjgh-2018-000873

Handling editor Seye Abimbola

Received 6 April 2018

Revised 24 July 2018

Accepted 27 July 2018
Check for updates

(C) Author(s) (or their employer(s)) 2018. Re-use permitted under CC BY-NC. No commercial re-use. See rights and permissions. Published by BMJ

${ }^{1}$ HRIDAY, New Delhi, Delhi, India ${ }^{2}$ Health Promotion Division, Public Health Foundation of India, Gurugram, India ${ }^{3}$ Nuffield Department of Population Health, University of Oxford, Oxford, UK

${ }^{4}$ Nossal Institute for Global Health, University of Melbourne, Melbourne, Victoria, Australia

Correspondence to Dr Monika Arora; monika@hriday-shan.org

\section{ABSTRACT}

India implemented larger 85\% pictorial health warnings on all tobacco products from 1 April 2016. However, to remove the last bit of glamour and attraction from the tobacco packs, it must now embrace plain packaging. Plain packaging prevents tobacco packs from carrying the tobacco industry brand imagery as mobile billboards. Postimplementation of larger $85 \%$ pictorial health warnings on all tobacco products, this analysis was undertaken to assess the feasibility of plain packaging as the next logical tobacco control policy measure in India. As part of this analysis, the research team reviewed the available literature on legal and policy challenges to plain packaging as a tobacco control policy initiative for India. Literature from 2010 to 2016 in English language was reviewed, which reveals that, India has taken several preparatory steps implemented by other countries like Australia and the UK that have introduced plain packaging, for example, stronger smoke-free laws, ban on tobacco advertising, promotion and sponsorship, increase in taxes and a report from civil society task force on plain packaging. The trade and investment agreements signed by India are also within the international trade norms relating to public health. A Private Member's Bill on plain packaging is also pending in the Parliament of India. Other potential challenges against such policy decision, for example, freedom of trade, right to property, violation of competition law and other laws including consumer protection laws, were found unsubstantiated by the research team. Plain packaging is the next logical step for tobacco control policy in India.

\section{INTRODUCTION}

Tobacco is the only legal product that kills over a million people and impoverishes around 15 million people annually in India. ${ }^{1}$ The total economic costs attributable to tobacco use from all diseases in India in 2011 were estimated at US\$22.4 billion. ${ }^{2}$ Yet, India remains one of the largest consumers of tobacco products in the world, second only to China. ${ }^{3}$ It is also one of the major growers of tobacco in the world.

Tobacco smoking is the second leading cause of preventable deaths globally. ${ }^{4}$ In response to this global epidemic, WHO
Summary box

Australia, the UK and several other countries have either implemented or plan to implement plain packaging of tobacco products.

- India has taken several preparatory tobacco control steps, which indicate its readiness to implement plain packaging of tobacco products.

- Existing domestic legislation and international trade obligations of India are not in conflict with plain packaging policy.

- Experience from other jurisdictions indicates tobacco industry as the major roadblock to implementing plain packaging.

- This paper will help governments and tobacco control advocates in low-income and middle-income countries, in working towards implementation of plain packaging of tobacco products.

developed and adopted the Framework Convention on Tobacco Control (FCTC) in 2003. The WHO FCTC outlines proven, cost-effective and evidence-based measures to combat this epidemic. ${ }^{5}$ From among the various evidence-based tobacco control measures recommended under the WHO FCTC, there has been an increasing interest among countries, including India, to implement standardised packaging or plain packaging to fight against the growing tobacco epidemic. ${ }^{5-7}$ As the term indicates, plain packaging aims to remove the last bit of glamour and attraction from all the tobacco packaging and prevent tobacco packs from carrying the tobacco industry brand imagery as mobile billboards. $^{8}$

This policy analysis was undertaken to assess the feasibility of introducing plain packaging in India and to assess if this public health measure contravenes any existing Indian legislation. This policy analysis also envisions identifying the key barriers and options to address them-in the backdrop of the Australian experience, and the global interest and 
emphasis on plain packaging of tobacco products. The study team identified and reviewed the national laws on plain packaging in Australia, ${ }^{9}$ the $\mathrm{UK}^{10}$ and the Private Members Bill on plain packaging in India, ${ }^{11}$ besidess 'Cigarettes and Other Tobacco Products (Prohibition of Advertisement and Regulation of Trade and Commerce, Production, Supply and Distribution) Act, 2003' (COTPA). ${ }^{12}$ The national and international laws and policies that could potentially be used by the tobacco industry to challenge a decision of implementing plain packaging in India were also identified and reviewed. Information was collected based on the recommendations of the Australia-India Institute Taskforce ${ }^{13}$ on Tobacco Control and an iterative method of web-based searching. Copies of the written policies regulating plain packaging in Australia were reviewed by the study team to understand how plain packaging has been introduced and regulated there. ${ }^{9}$ The study team reviewed legislation and regulations, which were likely to be used by the Indian tobacco industry to oppose plain packaging.

\section{PLAIN PACKAGING IN AUSTRALIA}

Canada was the first country to moot the idea of plain packaging of tobacco products, ${ }^{14}$ but it was Australia which became the first country to implement the provision from 1 December 2012. ${ }^{814}$ Despite having little basis for legal challenge, the tobacco industry vehemently opposed the plain packaging initiative in Australia on the ground of being in contravention of constitutional rights, the Trade-Related Intellectual Property Rights (TRIPS) Agreement and the Paris Convention, leading to substantial claims for compensation against the Australian Government. However, the Australian Government, based on recommendations of the National Preventative Health Taskforce, mandated standard plain packaging of all tobacco products to inter alia, reduce the appeal of tobacco products, increase the effectiveness of health warnings and prevent the design features of the pack from reducing the impact of prescribed government warnings. ${ }^{9}$ The Australian legislation was preceded by a series of evidence-based initiatives and was followed up with similar efforts after the implementation of the law, including an amendment to the domestic trademark law, to ensure successful implementation of the plain packaging law in the country. ${ }^{15}$

\section{INDIA-AUSTRALIA RESEARCH COLLABORATION ON PLAIN PACKAGING}

While Australia implemented plain packaging as a part of the comprehensive tobacco control effort, experts in tobacco control from Australian and Indian institutions collaborated to form a joint India-Australia high-level taskforce to explore plain packaging in India. The taskforce produced a comprehensive report, ${ }^{13}$ and a research paper on the feasibility of plain packaging in India. ${ }^{16}$ However, the taskforce had concluded that further research was required before such policy measures could be introduced. In the meantime, a Private Member's Bill was introduced in the Indian Parliament seeking amendment to the COTPA to include plain packaging of tobacco products. ${ }^{11}$ The legality of plain packaging under international laws has been established with the Australian experience and as noted by experts. ${ }^{15} 17$ Indeed, India has its own legal and constitutional framework distinct from Australia and any other country's experience in introducing and implementing plain packaging. Moreover, tobacco control measures often become the subject of litigation in Indian courts and legal barriers have been perceived as a threat to the realisation of plain packaging.

\section{WHO FCTC RECOMMENDS PLAIN PACKAGING}

The WHO FCTC prohibits any kind of advertisement of tobacco products and recommends ensuring clear health warnings on tobacco products. ${ }^{5}$ Article 11 of WHO FCTC requires parties to implement large health warnings on tobacco packages to increase public awareness about the dangers of tobacco use. ${ }^{5}$ Going a step ahead, the guidelines on Article 11 (packaging and labelling), ${ }^{6}$ and Article 13 (tobacco advertising, promotion and sponsorship), adopted by the Conference of the Parties in 2010, recommend that parties should consider adopting plain packaging. The Article 11 guidelines recommend that parties should consider adopting measures to restrict or prohibit the use of logos, colours, brand images or promotional information on packaging other than brand names and product names displayed in a standard colour and font style. ${ }^{6}$

\section{FCTC OBLIGATIONS 'NECESSARY', 'FAIR AND EQUITABLE'}

Although plain packaging is not expressly mentioned in the FCTC text, it has been clearly recommended under the guidelines for implementation of Articles 11 and $13{ }^{67}$ This makes plain packaging of tobacco products a necessary obligation for parties to FCTC. Furthermore, while dealing with the tobacco industry's challenge against larger graphic warning provisions in Uruguay, the tribunal held that the measures were based on and were in furtherance of the obligations and recommendations of the FCTC and thus not arbitrary, and do not violate the 'fair and equitable' treatment clause of the bilateral trade and investment treaties. ${ }^{18}$

\section{PICTORIAL HEALTH WARNINGS IN INDIA}

India was among the forerunners in FCTC negotiations and was among the first few nations to ratify the treaty and simultaneously adopt a national tobacco control legislation in 2003. Even before the national legislation came into force, the Courts in India had given directives to the state machinery to take strict measures to curb the tobacco epidemic by taking into consideration the constitutional duty of the state to protect public health. ${ }^{19} 20$ Consistent with the mandates of the FCTC, the Indian law also prohibited sale and import of any tobacco 
products without the specified health warnings on the tobacco packages. ${ }^{12}$ However, what followed was an unprecedented delay and dilution of the pictorial health warnings notified initially, which were implemented on all tobacco packs in the country 5 years later, from June 2009. ${ }^{21}$ Since 2009, India implemented pictorial health warnings covering $40 \%$ of the front panel of the pack (ie, $20 \%$ of the principal display area of the pack) with the health warnings rotated every 2 years. ${ }^{22}$ These inadequate warnings placed India at 138th position for size of health warnings. ${ }^{23}$ However, on 1 April 2016, India implemented the much-awaited larger health warnings that cover $85 \%$ of the tobacco packs on both sides with $60 \%$ pictorial and $25 \%$ textual warning. ${ }^{24}$ The only other countries in the world with larger warnings are Nepal and Vanuatu at $90 \%$ and the other countries to equate such large graphic health warnings are Thailand $(85 \%)$ followed by Australia at $82 \%$ and Uruguay as well as Sri Lanka at $80 \% .^{25}$ One of the most significant aspects of the new regulation is that it provides for a minimum size for the warnings, that is, not be $<3.5 \mathrm{~cm}$ (width) and $4 \mathrm{~cm}$ (height) so as to ensure that the warnings are legible, prominent and conspicuous. ${ }^{24}$

\section{THE LOGICAL NEXT STEP FOR TOBACCO CONTROL POLICY IN INDIA}

Adoption of the larger pictorial health warnings followed the recommendations made to Ministry of Health and Family Welfare, Government of India, by an expert committee constituted earlier in 2014 to look at global best practices and develop field tested India-specific pictorial health warnings. ${ }^{26}$ Although the warnings notified in October 2014 were to come into force from 1 April 2015 , they were delayed owing to an observation from the Committee on Subordinate Legislation of the Lok Sabha (Lower House of Indian Parliament). Later, due to strict direction from the Rajasthan High Court, ${ }^{27}$ it came into force from 1 April 2016. The Court also referred to "plain packaging as an improved and effective strategy, and therefore, suggested that it should be given a serious thought by legislature $^{\prime 27}$ The issue of plain packaging was specifically raised in and addressed by the Allahabad High Court, wherein the court directed the Centre and the State Governments to consider implementation of plain packaging of tobacco products and observed that, 'tobacco plain packaging measure would be a long-term investment to safeguard the health of the Indian youth'.28 The court strongly recommended the Indian government to to gather further evidence in support of plain packaging and implement plain packaging laws within the current tobacco control legislation in the country.

The Report of the India-Australia Taskforce on Tobacco Control had already outlined the public interest and also the public support for plain packaging as a policy intervention in India and recommended that India could implement plain packaging with some amendments in COTPA. $^{13}$ 16 This recommendation made immediate way to the Parliament, when an amendment to sections 3,5 and 7 of COTPA was introduced through a Private Member's Bill in the Parliament. ${ }^{11}$ The Bill proposes an increase in the size of the pictorial health warnings and prohibition on advertisements of tobacco products 'in' and 'on' packs and at point of sale by repealing the two provisos to section 5 of COTPA. Section 3 of the Bill proposes insertion of the following section 7A, specifically on plain packaging.

7A. Every package of cigarette or any other tobacco products shall comply with following requirements:

a. No business name or trademark or any other mark shall appear anywhere on the package, other than as permitted under this Act.

b. The business name or trademark or any other mark may appear on the package subject to following conditions:

A. it shall appear only once on the outer surface of the package;

B. it shall appear in one line only;

C. it shall appear horizontally below the specified warning with the font style and font size as may be prescribed.

c. The outer and inner surfaces of the package shall be of a specified colour and texture as may be prescribed.

d. The outer and inner surfaces of the package shall not have any embossing, ridges or any irregularities of shape or size, or any other embellishments.

e. The package shall not have any of the following features:

A. it shall not reveal any text or picture when scratched;

B. it shall not be made of such ink that appears or changes colour with passage of time;

C. it shall not be made of such ink that appear visible in certain light;

D. it shall not have any removable or folding tabs.

\section{INDIA'S PREPAREDNESS COMPARED WITH AUSTRALIA AND}

\section{THE UK}

The taskforce also suggested several other immediate, intermediate and long-term measures towards preparation and adoption of plain packaging in India, the foremost being the need to compile a body of evidence supporting plain packaging in the Indian context. The trajectory of Australian and the UK's experience, from preparation to the enactment and implementation of its legislation on plain packaging and the early outcomes compared with the developments in India (table 1) could provide an indication of India's preparedness before introducing this big-ticket tobacco control measure in the country.

\section{PROBABLE BARRIERS TO PLAIN PACKAGING IN INDIA}

Tobacco industry will be the biggest obstruction in the road to plain packaging in India: the industry has used intimidation to resist plain packaging in Australia, ${ }^{29}$ the UK and other countries. The tobacco industry in India will likely 
Table 1 The plain packaging trajectory for Australia, the UK and India

Tobacco control efforts, initiatives, evidence, policy decisions and

S. no. legislation

\begin{tabular}{|c|c|c|c|c|}
\hline 1 & Text warnings on cigarettes & 1973 & 1971 & 1975 \\
\hline 2 & Smoke-free laws initiated at some levels & 1985 & 2006 & 1996 \\
\hline 3 & Smoking prohibited in public vehicles & 1982 & 2007 & 1988 \\
\hline 4 & Tobacco advertising, promotion and sponsorship is banned & 1992 & & 2003 \\
\hline 5 & Graphic health warnings & 2006 & 2008 & 2009 \\
\hline 6 & $\begin{array}{l}\text { First published research study documenting public perception and } \\
\text { support for plain packaging }\end{array}$ & 2011 & 2011 & 2013 \\
\hline 7 & Stronger and larger pictorial health warnings implemented & 2012 & 2016 & 2016 \\
\hline \multirow[t]{3}{*}{8} & National Preventative Health Taskforce recommends plain packaging & 2010 & & \multirow{3}{*}{2012} \\
\hline & India-Australia Taskforce recommends plain packaging & & & \\
\hline & $\begin{array}{l}\text { Sir Cyril Chantler publishes independent report suggesting positive } \\
\text { impact of plain packaging }\end{array}$ & & 2014 & \\
\hline 9 & Plain packaging Bill introduced & 2011 & 2015 & 2012,2014 \\
\hline 10 & Plain packaging legislation implemented & 2012 & 2016 & - \\
\hline
\end{tabular}

initiate spurious cases of violation of constitutional rights including freedom to trade, loss of livelihood, right to property and other laws including competition and consumer protection laws. Similarly, the tobacco industry in India has strongly resisted efforts to strengthen the pictorial health warnings and the $85 \%$ pack warnings are currently under judicial review. ${ }^{30}$ These tactics have resulted in a delay and dilution of pictorial health warnings in India.

Provisions under multilateral and bilateral trade and investment treaties are being used by the tobacco industry against plain packaging efforts: tobacco companies in Australia, the UK and elsewhere have exploited investment protections within international investment agreements to challenge plain packaging. ${ }^{31}$ Tobacco companies claim that these laws violate trade and investment treaties and may result in the countries liability in huge compensation to the companies under the investor-state dispute settlement (ISDS). ${ }^{32}$ This insidious intimidation by the tobacco industry stands exposed in the claims filed against Uruguay's warning labels and branding measures and against Australia's plain packaging before Australia-Hong Kong ISDS and the dispute at the World Trade Organisation (WTO). ${ }^{33} 34$

However, legal experts suggest that plain packaging does not contravene a country's obligations under investment agreements or trade treaties and that public health has to be given prime importance. ${ }^{35}$ The importance of public health and the right of states to take measures aimed at protecting it are recognised across the international trade and investment regimes as 'both vital and important in the highest degree'. ${ }^{36}$

Plain packaging is consistent with the WTO norms: within the WTO regime, General Agreement on Tariffs and Trade Article XX(b) guarantees the Members' right to take steps necessary to protect the health of humans, animals and plants. ${ }^{37}$ While Article XIV(b) of the General Agreement on Trade in Services authorises Members to take measures for the protection of human, animal or plant life or health, ${ }^{38}$ and TRIPS Article 8.1 sets out the basic principle relating to health and allows Members to take measures for protecting public health. ${ }^{39}$ To make use of the health exceptions, WTO Agreements generally require the health measures be no more trade-restrictive than necessary. ${ }^{40}$ With respect to tobacco control, restrictions called for by the provisions in the FCTC may well be determined to be 'necessary' for health protection under the WTO rules. ${ }^{41}$ Unlike the tax increases and education programmes, plain packaging restricts the capacity of the tobacco packs to act as moving billboards. It aims to decrease consumers being attracted to appealing packs, which can be prevented only through standardised packing. Therefore, plain packaging, per se does not violate the WTO agreements including TRIPS agreement, and is 'necessary' and there is no 'alternative measure' that can achieve the desired objective. The Doha Declaration on TRIPS, ${ }^{42}$ and Public Health and the Punta del Este Declaration, ${ }^{43}$ further support this claim.

Overlapping laws and regulations: a lack of careful analysis of the legal and constitutional concerns with overlapping laws and regulations in India was identified as a barrier by the taskforce. These concerns have been summarised in table 2 along with a careful assessment mitigating the same.

\section{COUNTERING THE TOBACCO INDUSTRY CLAIMS}

The Australian and the UK's experience of implementing plain packaging of tobacco products makes it clear that the tobacco industry will remain the single largest barrier to implementation of an effective tobacco control measure such as plain packaging. ${ }^{16}$ 44-47 However, the tobacco 
Table 2 Assessment of key legislative and regulatory concerns

\begin{tabular}{|c|c|c|c|}
\hline Legislation & Concern & In reality & Remarks \\
\hline $\begin{array}{l}\text { Constitution of India } \\
\text { (Article 19(1)(g)) }\end{array}$ & $\begin{array}{l}\text { Plain packaging will infringe } \\
\text { freedom of trade }\end{array}$ & $\begin{array}{l}\text { This freedom is not absolute and Article } \\
19(6) \text { of the Constitution provides that } \\
\text { reasonable restrictions on trade may } \\
\text { be imposed for protecting interest of } \\
\text { the general public and may restrict any } \\
\text { trade and activity even to the exclusion } \\
\text { of all and also impose a total prohibition } \\
\text { on such trade. }\end{array}$ & $\begin{array}{l}\text { Total prohibition of tobacco } \\
\text { trade is possible while plain } \\
\text { packaging is no more than a } \\
\text { reasonable restriction in the } \\
\text { interest of public. }\end{array}$ \\
\hline
\end{tabular}

Constitution of India Plain packaging will infringe (Article 21) right to livelihood of those engaged in tobacco trade

Several studies have revealed that the industry exploits tendu leaf collectors (mostly tribals) and bidi rollers by forcing them to live in perpetual poverty with arduous working conditions and occupational health hazards.

\begin{tabular}{|c|c|c|c|}
\hline $\begin{array}{l}\text { Constitution of India } \\
\text { (Article } 300(A)) \\
\text { Trademarks Law, } \\
\text { TRIPS, etc }\end{array}$ & $\begin{array}{l}\text { Plain packaging will amount to } \\
\text { acquisition of property }\end{array}$ & $\begin{array}{l}\text { Although important, the right is not an } \\
\text { absolute one within the Constitution } \\
\text { or under trademark legislation and is } \\
\text { subject to the restrictions of Article 19(2) } \\
\text { of the Constitution of India. }\end{array}$ & $\begin{array}{l}\text { Property in this respect is } \\
\text { vested with no more than a } \\
\text { negative right. }\end{array}$ \\
\hline Competition Act & $\begin{array}{l}\text { Plain packaging will be trade } \\
\text { restrictive and anticompetitive }\end{array}$ & $\begin{array}{l}\text { As per section } 54 \text { of the Act, the Central } \\
\text { Government has power to exempt the } \\
\text { application of the very Act. }\end{array}$ & $\begin{array}{l}\text { There is constitutional } \\
\text { protection to take such action } \\
\text { under Article 19(6). }\end{array}$ \\
\hline Legal Metrology Act & $\begin{array}{l}\text { Plain packaging will affect } \\
\text { mandatory declarations on } \\
\text { prepackaged commodities }\end{array}$ & $\begin{array}{l}\text { Most of the mandatory declarations } \\
\text { under this law are same as notified } \\
\text { for tobacco products under COTPA } \\
\text { regulations. }\end{array}$ & $\begin{array}{l}\text { Law already exempts bidi } \\
\text { manufacturers on certain } \\
\text { declarations. }\end{array}$ \\
\hline
\end{tabular}

COTPA, Cigarettes and Other Tobacco Products (Prohibition of Advertisement and Regulation of Trade and Commerce, Production, Supply and Distribution) Act, 2003; TRIPS, Trade-Related Intellectual Property Rights.

industry's challenge against plain packaging is not sustainable on constitutional or national and international legal or treaty regime. Their claims before the Australian Constitutional Court, United Kingdom Court of Appeal and the ISDS have all been rejected. According to legal experts, the dispute at the WTO against the Australian plain packaging decision has little chance of success, ${ }^{15}$ and has already been decided in favour of Australia. ${ }^{48-50}$ Given the global attention and appetite for this significant tobacco control measure, WHO and the Secretariat for WHO FCTC has called on countries to get ready for the plain (standardised) packaging of tobacco products.

Another concern against adopting plain packaging emanates from the tobacco industry generated apprehensions related to violation of trade and investment agreements and to avoid claims of intellectual property rights infringement. However, a closer examination of the WTO agreements with given health exceptions, the Doha and Punta Del Este Declarations on public health and decisions of the WTO and other dispute settlement tribunals suggest that a country could successfully implement a plain packaging regulation if it is applied in a non-discriminatory manner. Moreover, both domestic and international laws regulating trademarks do not give any absolute right of use over a registered trademark. It merely confers a negative right against the use of that trademark by others.

Parties to the FCTC must be mindful of the fact that, it is not that only the WTO agreements are binding; parties must respect their obligation under the WHO FCTC Articles 11 and 13, which stipulate implementation of effective packaging and labelling of tobacco products, and prohibition of tobacco advertisement, promotion and sponsorships. FCTC recommends plain packaging as an effective means to implement the two treaty provisions. Even the Australian High Court while ruling in favour of the plain packaging regulations, highlighted the implication of being a party to WHO FCTC and the need to give effect to obligations thereunder. ${ }^{51}$

Moreover, the doctrine of Pacta sunt servanda contained in article 26 and article 27 of the Vienna Convention, 1980 lays down that every treaty in force is binding on the parties to it and must be performed in good faith and a party may not invoke the provisions of its internal law as a justification for its failure to perform a treaty obligation. ${ }^{52}$ It is also settled that when there is no conflict between 
the domestic law and a treaty obligation, Government instrumentalities should respect and implement the treaty obligations.

\section{CONCLUSION}

The developments related to implementation of larger pictorial health warnings indicate that India is at a ripe stage from where, if supported by the strong political will, plain packaging will be the next obvious and logical step in the armoury of tobacco control. It is expected that India will have to face unique challenge from the unregulated markets of bidi and smokeless forms of tobacco, sale of loose tobacco products and a myriad of tobacco product varieties, most of which are produced and marketed in the unorganised sector. However, with strategic planning and preparedness, such challenges could be avoided when advancing the plain packaging agenda. This may be feasible through ensuring provisions in the official draft amendment to COTPA, ${ }^{11}$ and second, supporting the Private Member's bill on the amendment to COTPA. In addition to the constitutional and legal backing for a public health policy like plain packaging of tobacco products, the overwhelming support of the general public provides the much-needed impetus for its consideration by the law makers. ${ }^{53}$

Given India's 85\% health warnings take a step closer to plain packaging and leaving not much space for tobacco industry to enhance appeal of the pack, plain packaging would still be useful as it will help in standardisation of packages across the myriad varieties of tobacco products available in India. At the risk of stating the obvious, provisions of WHO FCTC and the guidelines recommending plain packaging of tobacco products are not in conflict with any of the domestic laws of India, and rather complement COTPA. Considering the fact that several countries have already adopted plain packaging legislation, India, being a frontrunner in implementing stronger tobacco control measures, should also take the bold step before it is left far behind other countries.

Acknowledgements The authors would like to thank Ms Manjusha Chatterjee and Ms Karuvaki Mohanty for their research support and inputs on an initial draft of this work.

Contributors AY, MA, NG, PW and GPN contributed to developing the concept and design of the study. AY contributed to the planning and supervising data collection and management, data analysis, interpretation of data and drafting and revising the manuscript. MA, NG, PW, TR and GPN provided technical inputs on data analysis and interpretation of results. PW, MA, TR, NGP and NG contributed to revising the manuscript critically for intellectual contents. All the authors approved the final version of the manuscript and are accountable for the accuracy and integrity of any part of the work.

Funding This research received no specific grant from any funding agency in the public, commercial or not-for-profit sectors.

Competing interests None declared.

Patient consent Not required.

Provenance and peer review Not commissioned; externally peer reviewed.

Data sharing statement No additional data available for this study.

Open access This is an open access article distributed in accordance with the Creative Commons Attribution Non Commercial (CC BY-NC 4.0) license, which permits others to distribute, remix, adapt, build upon this work non-commercially, and license their derivative works on different terms, provided the original work is properly cited, appropriate credit is given, any changes made indicated, and the use is non-commercial. See: http://creativecommons.org/licenses/by-nc/4.0/.

\section{REFERENCES}

1. John RM, Sung HY, Max WB, et al. Counting 15 million more poor in India, thanks to tobacco. Tob Control 2011;20:349-52.

2. Ministry of Health and Family Welfare, 2014. Economic Burden of Tobacco Related Diseases in India New Delhi Ministry of Health and Family Welfare http://www.searo.who.int/india/topics/tobacco/ economic_burden_of_tobacco_related_diseases_in_india_executive summary.pdf (accessed 5 Apr 2015).

3. World Health Organization, 2017. Tobacco http://www.searo.who.int/ india/topics/tobacco/en/ (accessed 10 Oct 2017).

4. Institute for Health Metrics and Evaluation, 2017. IHME Data: GBD Results Tool http://ghdx.healthdata.org/gbd-results-tool (accessed 10 Oct 2017).

5. World Health Organization. WHO Framework convention on tobacco control. Geneva, Switzerland: World Health Organization, 2003.

6. World Health Organization. Guidelines for implementation of Article 11. Guidelines on packaging and labelling of tobacco products. Geneva: World Health Organization, 2017. (accessed 8 Sep 2017).

7. World Health Organization. Guidelines for implementation of Article 13. Guidelines on tobacco advertising, promotion and sponsorship. Geneva: World Health Organization, 2017. (accessed 8 Sep 2017).

8. Chapman S, Freeman B. Removing the emperor's clothes: Australia and tobacco plain packaging. Sydney: Sydney University Press, 2014.

9. Australian Government, 2011. Tobacco Plain Packaging Act 2011 https://www.legislation.gov.au/Details/C2011A00148 (accessed 8 Sep 2017)

10. UK Government, 2015. The standardised packaging of tobacco products regulations $2015 \mathrm{http}: / / w w w . l e g i s l a t i o n . g o v . u k / u k s i / 2015 /$ 829/pdfs/uksi_20150829_en.pdf (accessed 8 Sep 2017).

11. Panda $B, 2014$. The cigarettes and other tobacco products (prohibition of advertisement and regulation of trade and commerce, production, supply and distribution) amendment bill, 2014 http://164.100.47.4/BillsTexts/LSBillTexts/Asintroduced/1432LS.pdf (accessed 10 Oct 2017).

12. Ministry of Health and Family Welfare. The cigarettes and other tobacco products (prohibition of advertisement and regulation of trade and commerce, production, supply and distribution) Act, 2003. New Delhi: Government of India Press, 2003.

13. Australia India Institute, 2012. Report of the Australia India Institute taskforce on tobacco control-plain packaging of tobacco products https://www.aii.unimelb.edu.au/publications/non-communicablediseases/ (accessed 10 Oct 2017).

14. Cunningham R, Kyle K. The case for plain packaging. Tob Control 1995;4:80-6.

15. Liberman J. Plainly constitutional: the upholding of plain tobacco packaging by the High Court of Australia. Am J Law Med 2013;39:361-81.

16. Arora M, Tewari A, Grills N, et al. Exploring perception of indians about plain packaging of tobacco products: a mixed method research. Front Public Health 2013;1:35.

17. Anderson $A$. The legality of plain packaging under international law. 49: Economic and Political Weekly, 2014.

18. Tobacco Free Kids, 2016. Philip Morris v Uruguay: findings from the international arbitration tribunal. https://www.tobaccofreekids.org/ assets/content/press_office/2016/2016_07_12_uruguay_factsheet. pdf (accessed 17 Oct 2017)

19. Rights GH, Murli S, v D, 2017. Union Of India and Others (2001) 8 SCC 765; AIR 2002 SC 40; 2002 (1) ALD 88 SC; 2001 (6) ALT 35 SC. http://www.globalhealthrights.org/asia/murli-s-deora-v-union-ofindia-and-ors/ (accessed 17 Sep 2017).

20. Tobacco Free Kids, 2015. Ramakrishnan and Anr. v. State of Kerala and Ors, AIR 1999 Kerala 385, High Court of Kerala (1999). http:// www.tobaccocontrollaws.org/litigation/decisions/in-19990712ramakrishnan-and-anr.-v.-state (accessed 12 Sep 2017).

21. Arora M, Yadav A. Pictorial health warnings on tobacco products in India: sociopolitical and legal developments. Natl Med J India 2010;23:357-9.

22. Ministry of Health and Family Welfare, 2008. GSR 182(E): The Cigarettes and Other Tobacco Products (Packaging and Labelling) Rules 2008. https://www.tobaccocontrollaws.org/files/live/India/ India\%20-\%20G.S.R.\%20182\%28E\%29\%20-\%20national.pdf (accessed 13 Sep 2017). 
23. Canadian Cancer Society. Cigarette package health warnings: international status report. Fourth edn, 2014. (accessed 5 Apr 2015).

24. Ministry of Health and Family Welfare, 2014. Notification - GSR 727(E) Cigarettes and Other Tobacco Products (Packaging and Labelling) Amendment Rules, 2014. http://www.tobaccolabels.ca/ wp/wp-content/uploads/2014/11/India-2014-Cigarettes-and-otherTobacco-Products-Amendment-Rules1.pdf (accessed 5 Apr 2015).

25. Canadian Cancer Society. Cigarette package health warnings: international status report. Fifth edn, 2016. (accessed 17 Oct 2017).

26. Sharma NC, 2014. Tobacco firms ordered to print bigger health warnings on packets. http://www.dailymail.co.uk/indiahome/ indianews/article-2794738/tobacco-firms-ordered-print-biggerhealth-warnings-packets.html (accessed 13 Sep 2017).

27. Joshi R. Tobacco Free Kids, 2015. Union of India \& Ors., WP No. 8680/2015. http://www.tobaccocontrollaws.org/litigation/decisions/ in-20150703-rahul-joshi-v.-union-of-india (accessed 13 Sep 2017).

28. Tobacco Free Kids, 2015. Love Care Foundation v. Union of India and Others, Writ Petition No.1078 (M/B) OF 2013. http://www. tobaccocontrollaws.org/litigation/decisions/in-20140721-love-carefoundation-v.-union- (accessed 13 Sep 2017).

29. Schneider J, 2012. Australia plain-pack law challenged by tobacco companies. https://www.stopcorporateabuse.org/news/australiaplain-pack-law-challenged-tobacco-companies (accessed 13 Sep 2017).

30. The Hindu, 2016. HC begins hearing on petitions against bigger pictorial warning on tobacco packs. http://www.thehindu.com/news/ cities/bangalore/HC-begins-hearing-on-petitions-against-biggerpictorial-warning-on-tobacco-packs/article14588794.ece (accessed 13 Sep 2017).

31. Voon T, Mitchell A. Time to Quit? Assessing international investment claims against plain tobacco packaging in Australia. J Int Eco Law 2011;14:515-52.

32. Shukla S, 2014. International trade impacts tobacco control. https:// www.modernghana.com/news/579077/1/international-tradeimpacts-tobacco-control.html (accessed 18 Sep 2007).

33. Saez C, New W, 2014. WTO to consider five Australia plain packaging disputes under one panel. https://www.ip-watch.org/ 2014/04/26/wto-to-consider-australia-plain-packaging-disputesunder-one-panel/ (accessed 19 Sep 2007).

34. World Health Organization, 2017. Sixth session of the conference of the parties to the WHO FCTC. http://www.who.int/fctc/cop/ sessions/cop6/en/ (accessed 18 Sep 2017).

35. Davison M, Liberman J, Mitchell A, 2014. Responding to the tobacco industry's claims that plain packaging breaches international trade and investment law. http://www.mccabecentre.org/blog/respondi ngtothetobaccoindustrysclaims.html (accessed 18 Sep 2014).

36. World Trade Organization. European Communities - measures affecting asbestos and asbestos-containing products. Report of the Appellate Body: World Trade Organization, 2001.

37. World Trade Organization, 2017. General Agreement on Tariffs and Trade 1994. https://www.wto.org/english/res_e/booksp_e/analytic index_e/gatt1994_07_e.htm\#article20A (accessed 17 Oct 2017).

38. World Trade Organization, 2017. General agreement on trade in services. https://www.wto.org/english/res_e/booksp_e/analytic_ index_e/gats_02_e.htm\#article14A (accessed 17 Oct 2017).
39. World Trade Organization, 2017. Agreement on trade-related aspects of intellectual property rights. https://www.wto.org/english/res_e/ booksp_e/analytic_index_e/trips_01_e.htm\#article8A (accessed 17 Oct 2017).

40. World Trade Organization, 2017. Technical barriers to trade. https:// www.wto.org/english/tratop_e/tbt_e/tbt_e.htm (accessed 18 Sep 2017)

41. World Trade Organization, World Health Organization, 2002. WTO agreements \& public health: a joint study by the WHO and WTO Secretariat. https://www.wto.org/english/res_e/booksp_e/who_wto_ e.pdf (accessed 18 Sep 2017)

42. World Trade Organization. Declaration on the TRIPS agreement and public health. 2001 https://www.wto.org/english/thewto_e/minist_e/ min01_e/mindecl_trips_e.htm (accessed September 19 2017).

43. WHO Framework Convention on Tobacco Control, 2010. Punta del Este Declaration on the Implementation of the WHO Framework Convention on Tobacco Control. http://apps.who.int/gb/fctc/PDF/ cop4/FCTC COP4(5)-en.pdf (accessed 19 Sep 2017).

44. Webster PC. Tobacco control measures under industry assault. CMAJ 2011;183:E1233-4.

45. Mackey TK, Liang BA, Novotny TE. Evolution of tobacco labeling and packaging: international legal considerations and health governance. Am J Public Health 2013;103:e39-43.

46. Voon T, Mitchell AD, Liberman J. Public health and plain packaging of cigarettes: legal issues. Melbourne: Edward Elgar Publishing, 2012.

47. Crosbie E, Glantz SA. Tobacco industry argues domestic trademark laws and international treaties preclude cigarette health warning labels, despite consistent legal advice that the argument is invalid. Tob Control 2014;23:e7.

48. The Conversation Media Group Ltd. World Trade Organisation gives Australia's plain tobacco packs the (draft) thumbs up. $2017 \mathrm{http} / / /$ theconversation.com/world-trade-organisation-gives-australiasplain-tobacco-packs-the-draft-thumbs-up-77234 (accessed 18 Oct 2017).

49. The Guardian, 2017. Tobacco industry suffers defeat as WTO upholds Australia's plain packaging laws. https://www.theguardian. com/global/2017/may/05/australias-defeats-wto-challenge-to-plainpackaging-of-tobacco (accessed 18 Oct 2017).

50. Miles T, Geller M, 2017. Australia wins landmark WTO tobacco packaging case - Bloomberg. https://www.reuters.com/article/ us-wto-tobacco-australia/australia-wins-landmark-wto-tobaccopackaging-case-bloomberg-idUSKBN1801S9 (accessed 18 Oct 2017).

51. Fletcher D. JT International SA v Commonwealth: tobacco plain packaging. Sydney Law Review 2013;35:827-43

52. United Nations, 1980. Vienna Convention on the law of treaties (with annex). Concluded at Vienna on 23 May 1969. https://treaties.un. org/doc/publication/unts/volume\%201155/volume-1155-i-18232english.pdf (accessed 18 Oct 2017).

53. Hughes N, Arora M, Grills N. Perceptions and impact of plain packaging of tobacco products in low and middle income countries, middle to upper income countries and low-income settings in highincome countries: a systematic review of the literature. BMJ Open 2016;6:e010391. 